\title{
Rolpersepsies van dosente van eerstejaars in die natuurwetenskappe: 'n Fokus op geslagsverskille
}

\begin{tabular}{|c|c|}
\hline \multicolumn{2}{|c|}{$\begin{array}{l}\text { Authors: } \\
\text { Melanie Jacobs }{ }^{1} \\
\text { Gerrie J. Jacobs }{ }^{2}\end{array}$} \\
\hline \multicolumn{2}{|c|}{$\begin{array}{l}\text { Affiliations: } \\
{ }^{1} \text { Unit for Programme, } \\
\text { Enrolment and Quality } \\
\text { Management, University of } \\
\text { Johannesburg, Auckland Park } \\
\text { Kingsway Campus, } \\
\text { South Africa }\end{array}$} \\
\hline \multicolumn{2}{|c|}{$\begin{array}{l}{ }^{2} \text { Department of Science } \\
\text { and Technology Education, } \\
\text { University of Johannesburg, } \\
\text { Auckland Park Kingsway } \\
\text { Campus, South Africa }\end{array}$} \\
\hline \multicolumn{2}{|c|}{$\begin{array}{l}\text { Correspondence to: } \\
\text { Gerrie Jacobs }\end{array}$} \\
\hline \multicolumn{2}{|c|}{$\begin{array}{l}\text { Email: } \\
\text { gjacobs@uj.ac.za }\end{array}$} \\
\hline \multicolumn{2}{|c|}{$\begin{array}{l}\text { Postal address: } \\
\text { PO Box 524, Auckland Park } \\
\text { 2006, South Africa }\end{array}$} \\
\hline \multicolumn{2}{|c|}{$\begin{array}{l}\text { Dates: } \\
\text { Received: } 23 \text { Feb. } 2014 \\
\text { Accepted: } 18 \text { Sept. } 2014 \\
\text { Published: } 24 \text { Nov. } 2014\end{array}$} \\
\hline \multicolumn{2}{|c|}{$\begin{array}{l}\text { How to cite this article: } \\
\text { Jacobs, M. \& Jacobs, G.J., } \\
2014 \text {, 'Rolpersepsies van } \\
\text { dosente van eerstejaars in } \\
\text { die natuurwetenskappe: 'n } \\
\text { Fokus op geslagsverskille', } \\
\text { Suid-Afrikaanse Tydskrif } \\
\text { vir Natuurwetenskap en } \\
\text { Tegnologie 33(1), Art. \#857, } \\
9 \text { pages. http://dx.doi. } \\
\text { org/10.4102/satnt.v33i1.857 }\end{array}$} \\
\hline \multicolumn{2}{|c|}{$\begin{array}{l}\text { Copyright: } \\
\text { (C) 2014. The Authors. } \\
\text { Licensee: AOSIS } \\
\text { OpenJournals. This work } \\
\text { is licensed under the } \\
\text { Creative Commons } \\
\text { Attribution License. }\end{array}$} \\
\hline \multicolumn{2}{|l|}{ Read online: } \\
\hline 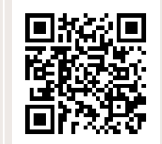 & $\begin{array}{l}\text { Scan this QR } \\
\text { code with your } \\
\text { smart phone or } \\
\text { mobile device } \\
\text { to read online. }\end{array}$ \\
\hline
\end{tabular}

Vanweë 'n merkbare verhoging in die aantal van studente aan Suid-Afrikaanse openbare universiteite gedurende die afgelope twee dekades het aansienlik meer 'nietradisionele' studente dié sektor betree. Sodanige studente beskik tipies oor onbevredigende skoolprestasievlakke en kommunikasievaardighede (veral in Engels) en het meestal eerstegenerasie-status. Die Fakulteit Natuurwetenskappe aan die Universiteit van Johannesburg (UJ) het in 2007 'n Eerstejaar-Akademie, oftewel First Year Academy (FYA) gestig. Die FYA verteenwoordig 'n praktykgemeenskap vir die dosente van eerstejaars, bevorder optimale leer by studente en verwag van dosente om die fasilitering van hul leerstrategieë te optimaliseer. Navorsingsgewys is weinig bekend oor die rolaanpassings wat van die dosente van eerstejaars in natuurwetenskappe verwag (of waartoe hulle gedwing?) word om in sulke omstandighede te maak. Altesaam 53 eerstejaardosente (60\% vroulik) was betrokke by 'n tipe Likertskaal-opname (literatuurgevalideerd). Die opname het persepsies aan die lig gebring ten opsigte van agt literatuurgebaseerde rolle wat dosente kan of behoort te vertolk wanneer hulle eerstejaarstudente onderrig, sowel as hul vaardigheid ter vervulling van sodanige rolle. Die Mann-Whitney $U$-toets het beduidende verskille in die persepsies van die belangrikheid van en vaardigheid in rolle tussen manlike en vroulike dosente getoon ten opsigte van sommige van die rolle. 'n Statisties beduidende verwantskap tussen hul geslag en die menings (asook optrede) van natuurwetenskapdosente vir eerstejaars aan UJ is ook te bespeur. Die bou van kapasiteit, gerig op die meer bedrewe vertolking van die rolle van kursusontwerper, onderriggewer, kursusbestuurder en eweknie-konsultant, word as uiters belangrik beskou. ' $n$ Professionele ontwikkelingsprogram spesifiek vir hierdie doel ontwerp, is vanaf 2014 deur die Fakulteit Natuurwetenskappe se Eerstejaar- Akademie aangebied.

Role perceptions of lecturers of first year science students: A focus on gender differences. A marked increase in student enrolments in South African public universities over the last two decades, allowed substantially more 'nontraditional' students into the sector. These students typically have unsatisfactory levels of school performance, lack communication skills (especially in English) and mostly have first-generation status. The Faculty of Science at the University of Johannesburg (UJ) established its First Year Academy (FYA) in 2007. The FYA, a community of practice for lecturers of first-year students, promotes optimal student learning, and expects lecturers to optimise their facilitation of learning strategies. Not much is known (research-wise) about role adaptions that lecturers of first-year students (especially in science faculties) are expected (forced?) to make in such circumstances. A literature-validated Likerttype questionnaire, involving 53 first-year lecturers (almost 60\% females), was subsequently administered. The survey gathered perceptions in respect of eight literature-based roles that lecturers (could or should) play when dealing with first-year students, as well as their selfappraised competence in fulfilling these roles. The Mann-Whitney $U$-test revealed significant differences between the perceived role importance and competence of male and female lecturers in respect of certain roles. The study revealed a significant relationship between the gender and opinions (and also behaviours) of science lecturers for first-year students at UJ. Capacity building geared at the more proficient execution of the roles of course designer, teacher, course manager and peer consultant is regarded as vital. A tailor-made professional development programme is offered by the Faculty of Science's FYA as of 2014.

\section{Inleiding, agtergrond en doel van die navorsing}

Sedert die negentigerjare het die Suid-Afrikaanse hoëronderwyssektor van 'n feitlik elite- na bykans 'n massastelsel omgeskakel. Studentetoelatings het van 495356 tot 937455 gestyg, wat 'n groeikoers van 89\% tussen 1994 en 2012 verteenwoordig (Republic of South Africa 2012:37). 'n Groter getal sogenaamde nietradisionele studente (Giancola, Munz \& Trares 2008) met kenmerkend gebrekkige vorige onderwyservaring, onbevredigende skoolprestasie, 'n 
gebrek aan kommunikasievaardighede (veral in Engels) en eerstegenerasie-status, het toelating tot hoër onderwys verkry (Cavote \& Kopera-Frye 2007; Olive \& Russ 2010). Die ouers of voogde van eerstegenerasie-studente beskik tipies nie oor hoëronderwyskwalifikasies nie, of het dalk begin studeer, maar nie 'n kwalifikasie behaal nie (Pike \& Kuh 2005).

Wêreldwyd word verskeie benaderings, gerig op die toenemend meer effektiewe en doelgerigte oorskakeling van studente na hoër onderwys, deur hoëronderwysinstellings geïmplementeer, terwyl sogenaamde ervaringsprogramme vir eerstejaars (First Year Experience [FYE] programmes) waarskynlik onlangs die mees betekenisvolle dividende gegenereer het (Jacobs 2010). In Suid-Afrika het die Universiteit van Stellenbosch hul Eerstejaar-Akademie (First Year Academy [FYA]) in 2007 bekend gestel (Leibowitz, Van der Merwe \& Van Schalkwyk 2009:3), terwyl die Universiteit van Johannesburg (UJ) hul FYE-program in 2009 geloods het (UJ 2009). Dié program berus op tien beginsels, waarvan veral die volgende twee ter sake is:

- It is incumbent on the university to ensure that students are provided with enabling learning environments.

- The challenge of first year teaching requires special expertise from the academic staff, who must in turn be assisted in meeting these challenges. (n.p.)

Die UJ se Fakulteit Natuurwetenskappe het ook in 2007 met aanvoorwerk vir die daarstelling van hul eie FYA begin en dit het voor die einde van die jaar formeel tot stand gekom. Die FYA dien as 'n gemeenskapspraktyk vir dosente van eerstejaarstudente en streef daarna om Ernest Boyer se Scholarship of Teaching te bevorder (Boyer 1997). Baie is reeds geskryf oor die oorgang van studente na hoër onderwys (Bowles et al. 2011; Jacobs 2010; Kift 2009; en andere), maar volgens Corkill, Elkington en Lawrence (2011:118) '... far less is known about the transitional experiences of academic staff who themselves support transitional students' (skrywers se klem). Voorgenoemde som die navorsingsprobleem op wat in dié studie ondersoek word.

Hierdie navorsing het ten doel om, wat as die belangrikheid van rolle beskou word, asook die vermeende vaardigheid van dosente in die Fakulteit Natuurwetenskappe aan die UJ, wat eerstejaarstudente in 'n 21ste eeuse Suid-Afrika onderrig, onder die loep te neem. Die Fakulteit se FYA onderneem navorsing oor strategieë en dosenterolle, ten einde eerstejaarstudente meer doeltreffend te kan onderrig (UJ 2013). Aanpassings aan die gebruiklike rolle van dosente vir eerstejaars word aanbeveel, terwyl toepaslike optrede en vaardighede ontwikkel behoort te word, veral aangesien die akademiese sukses van eerstejaarstudente in die natuurwetenskappe vir sowel die Fakulteit as die Universiteit ' $n$ belangrike prioriteit is.

\section{Literatuurperspektiewe}

Twee aanvullende stelle literatuurperspektiewe word vir die doel van hierdie navorsing as relevant beskou. Enkele onderrigstrategieë wat hoëronderwysinstellings ten opsigte van eerstejaarstudente implementeer, word onder die loep geneem, waarna die verwagte en veranderende rolle en vaardighede van dosente, wat eerstejaarstudente onderrig, beredeneer word.

\section{Onderrigstrategieë vir eerstejaarstudente}

Wetenskaplike dialoog oor die oorgang van studente na hoër onderwys is reeds vanaf die sewentigerjare goed gevestig (Akerlind 2005) en word gedurende die laaste dekade aktief deur Suid-Afrikaanse universiteite nagestreef. Onderstaande internasionale en nasionale strategieë blyk aansienlike sukses op hierdie gebied te genereer.

\section{Gespesialiseerde First Year Experience-sentrums}

Gespesialiseerde FYE-sentrums om die oorgang van studente na hoëronderwyskurrikula en-standaarde te vergemaklik, soos die Division for Academic Enhancement (University of Georgia) kom algemeen in die VSA voor en neem toe in Europese, Asiatiese, Britse en Australiese hoëronderwyssektore (Meyers \& Ryan 2008).

\section{Formele studente-oriënteringsprogramme}

Universiteite bied formele oriënteringsprogramme (induksieprogramme) vir oorgangstudente aan (Kift 2008). Die UJ se Fakulteit vir Natuurwetenskappe (UJ 2013) bied 'n volledige eerstejaarseminaar as kredietdraende module aan, waardeur studente se laboratorium-, rekenaar-, taal- en wiskundige bedrewenheid reeds voor die aanvang van die akademiese jaar ontwikkel word.

\section{Ondersteuningsprogramme en -strukture}

Kift (2008:16) waarsku dat' ... few assumptions can be made about students' entering knowledge, skills and attitudes'. Pogings ten bate van die maklike oorgang van studente sluit'n raamwerk van akademiese vaardighede in (Grayson 1997) en het ook ten doel om te voldoen aan die uitdagings van veeltaligheid en diversiteit in die Suid-Afrikaanse hoëronderwyssektor, leeren skryfstrategieë, sowel as aan tutor- en mentorprogramme (Bowles et al. 2011:69).

\section{Gespesialiseerde kurrikulumontwerp}

Grondfasemodules is kenmerkend van pogings tot kurrikulumbelyning aan die meeste Suid-Afrikaanse universiteite (Hay \& Marais 2004). Die UJ se Fakulteit Natuurwetenskappe (Jacobs 2010) bied 'n generiese eerste semester van fundamentele wetenskapmodules aan, met artikulering tot natuurwetenskap- en ingenieursprogramme.

Voorgenoemde strategieë is grootliks afhanklik van dosente se vermoë om hul tradisionele rolle en optredes proaktief te herken en aan te pas, ten einde beter ondersteuning aan die groeiende getal nietradisionele studente te bied. Die tweede stel literatuurperspektiewe fokus op beoogde dosenterolle en -vaardighede (ter nastrewing van bogenoemde) 


\section{Dosenterolle en -vaardighede}

\section{Generiese dosenterolle en -vaardighede}

Volgens Lentell (2003) is doeltreffende dosente vakkundiges, luisteraars, kommunikeerders, afrigters, leerfasiliteerders, mentors, probleemoplossers, ontwerpers, ondersteuners en hulpbronkoördineerders. Cornelius en Higgison (2000) maak 'n opsomming van 11 literatuurondersteunde rolle en ná bestudering van die optrede van Skotse eerstejaarsdosente genereer Senga Briggs (2005:257-266) 'n sogenaamde 'generic role model' wat op dosente in alle leeromgewings toepaslik sou kon wees. Briggs (2005:264) se model (Figuur 1) bevat onderskeidelik agt sogenaamde kern- ('core') en agt periferiese ('peripheral') rolle, aangetoon in die buitenste en binneste sirkels.
Die agt kernrolle is inherent verwant en sluit die verwagte repertoire van optredes deur dosente in, terwyl die periferiese rolle minder of meer prominent kan wees, afhangende van die konteks. Volgens Briggs (2005) beskou die Skotse dosente al agt kernrolle in haar studie as belangrik, maar bemerk hulle verskeie vaardigheidsgapings ter vervulling van hierdie rolle.

\section{Dosenterolle by die onderrig van eerstejaarstudente}

Daar word van dosente wat eerstejaarstudente (veral die hedendaagse generasie studente) onderrig, verwag om hierdie generiese rolle aan te pas deur hulle in die student se skoene te plaas (Leibowitz et al. 2009). Hulle behoort studente in hul kursusse te laat tuis voel. Eerstejaarstudente

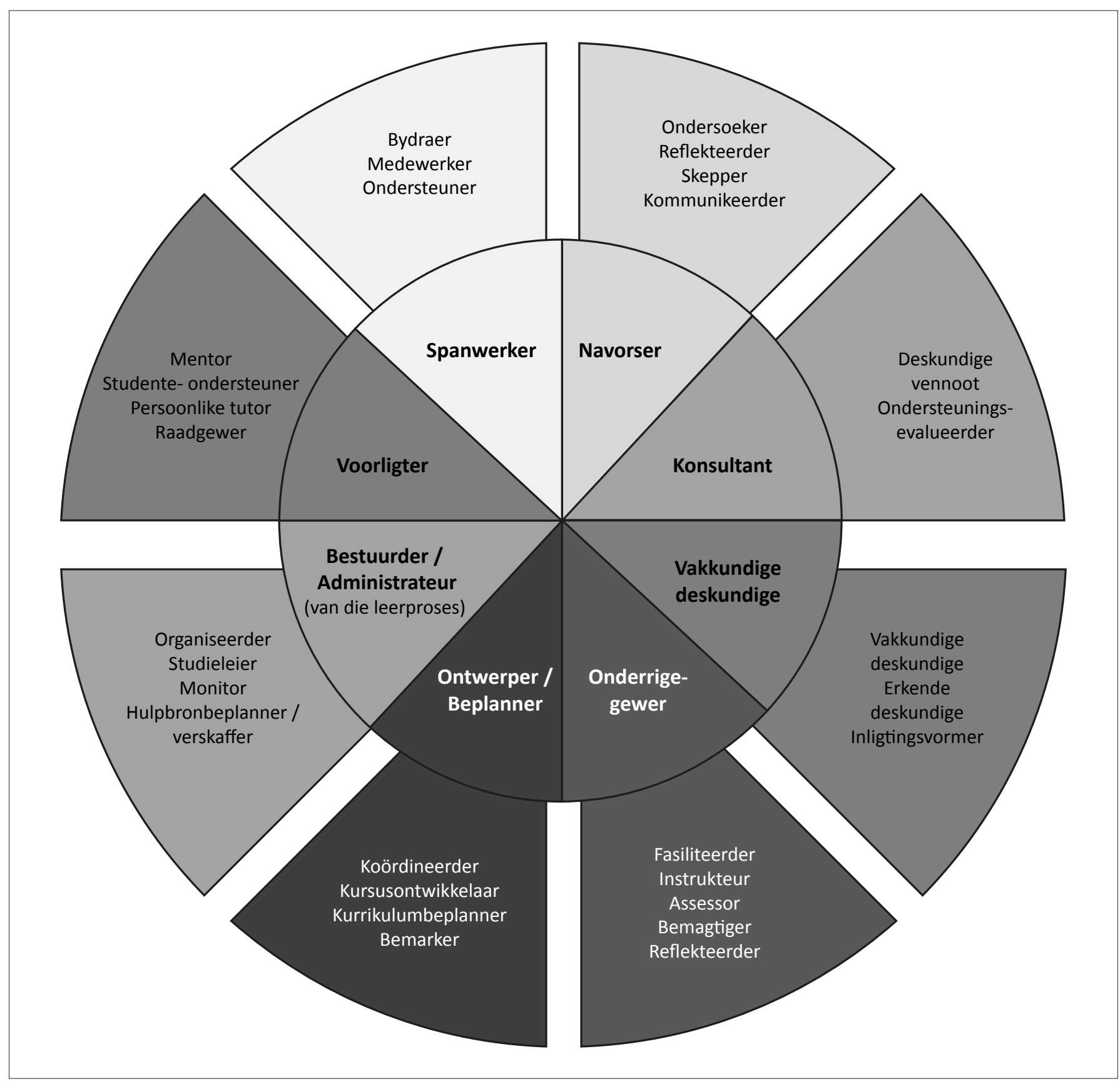

Bron: Briggs, S., 2005, 'Changing roles and competencies of academics', Active Learning in Higher Education 6(3), 256-268. http://dx.doi.org/10.1177/1469787405057753 met outeurs se eie konstruksie FIGUUR 1: Agt generiese rolle van dosente vir eerstejaars in hoëronderwys-omgewings. 
in die huidige hoëronderwysbedeling maak toenemend op dosente staat om geesdriftige en toeganklike motiveerders, mentors en voorligters te wees, wat harde werk en prestasie beloon (Leibowitz et al. 2009).

\section{Die invloed van geslag op dosenterolle in spesifiek natuurwetenskapfakulteite}

In die meeste skoolonderwysstelsels word studente deur onderwyseresse onderrig. Natuurwetenskapfakulteite word reeds eeue lank deur mansdosente oorheers (Corkill et al. 2011) en dit is steeds die geval. Die Briggs-studie (2005) toon dat mansdosente verkieslik hul kundigheid en status deur middel van hul lesings demonstreer, terwyl vrouedosente gemakliker is om te luister en advies te gee aan die hand van verskeie onderrig- en leermetodes. Arbuckle en Williams (2003) beskou warmte en medemenslikheid as tipiese vroulike kenmerke, en dinamiek en gretigheid meer as manlike eienskappe.

\section{Rolpersepsies van Natuurwetenskapdosente: 'n Empiriese ondersoek Navorsingsmetode en -ontwerp}

\section{Navorsingsbenadering}

Die ondersoek verteenwoordig 'n kwantitatiewe benadering, gebaseer op die aanname dat die veranderlikes van belang (die persepsies van dosente van eerstejaars ten opsigte van die rolle wat hulle speel en hul vaardigheid om elke rol te vertolk) gekwantifiseer en gemeet kan word. Hierdie benadering is van nature postpositivisties (Heppner \& Heppner 2004:143), wat veronderstel dat 'n eksterne werklikheid onafhanklik van die navorsingskonteks bestaan, maar dat sodanige werklikheid nie ten volle, asook nie vanuit slegs 'n enkele perspektief geken kan word nie. Vanuit hierdie perspektief is die doel van die empiriese ondersoek om sin te maak van die kompleksiteit van die onderrig- en leerkonteks waarbinne dosente van eerstejaarstudente in natuurwetenskappe aan UJ funksioneer. Die bevindinge behoort, indien nodig en toepaslik, riglyne vir toepassing deur die Fakulteit se FYA te verskaf. Die postpositivistiese benadering het nie ten doel om teorieë, modelle, raamwerke, riglyne of programme te genereer wat absolute waarhede oor die werklikheid van die respondente weerspieël nie. Die uitkomste behoort eerder beoordeel te word ten opsigte van die gebruikswaarde (substantiewe en praktiese uitvoerbaarheid) van die bevindinge wat gegenereer is.

\section{Respondente en etiese oorwegings}

Steekproefneming het geskied tydens die Fakulteit Natuurwetenskappe se jaarlikse FYA-seminaar in November 2012, nadat dosente van eerstejaars die datainsamelingsinstrument (omskryf in die volgende subafdeling) voltooi het. Ter wille van etiese maatreëls is alle respondente breedvoerig ingelig oor die doel en aard van die studie, die oorsprong, aard en voorgenome aanwending van die datainsamelingsinstrument, dat deelname vrywillig is (en dat hulle uit vrye wil in enige stadium, sonder enige nagevolge kon onttrek), asook dat hul anonimiteit en die vertroulikheid van die ingesamelde data gewaarborg is. Individuele toestemming is uiteindelik deur 53 deelnemers gegee. 'n Biografiese analise (Tabel 1) dui daarop dat die respondente gekarakteriseer kan word as natuurwetenskapdosente van eerstejaars wat merendeels vroulik (59\%) is, oorwegend swart (meer as 'n derde) óf wit (meer as die helfte), meestal Engels- of Afrikaanssprekend (saam $72 \%$ van die groep) en relatief ervare (twee derdes het meer as vyf [5] jaar ervaring van hoër onderwys, asook ervaring van die onderrig van eerstejaars).

\section{Data-insamelingsinstrument}

'n Literatuurgevalideerde gestruktureerde vraelys, gebaseer op Briggs (2005) se weergawe, is gebruik om inligting van die respondente te verkry. Die doel was om hul persepsies oor die belangrikheid van die rolle te meet wat hulle tydens die onderrig van eerstejaarstudente vertolk, asook die mate waarin hulle hulself as vaardig (of minder vaardig) beskou in die vertolking van sodanige rolle, indien die agt kernrolle van Briggs (2005:264) in berekening gebring word. Respondente is versoek om hul persepsie van die belangrikheid van elke rol, sowel as hul vaardighede in die vertolking van sodanige rolle op 'n 5-punt-Likertskaal aan te dui (vanaf 1 [nie van belang of vaardig] tot 3 [taamlik belangrik of vaardig] tot 5 [baie belangrik of vaardig]). Die vernaamste verpligtinge en verantwoordelikhede wat met elke rol verband hou, is omskryf (Tabel 2) en aan hulle gekommunikeer, ten einde potensiële onsekerheid te verminder.

\section{Betroubaarheids- en geldigheidsmaatreëls}

Ingesamelde Likertskaal-data is met behulp van die Statistiese Pakket vir die Sosiale Wetenskappe (SPSS) onderwerp aan die nodige betroubaarheids- en geldigheidstoetse. Die bevindinge word opsommend weergegee (vergelyk Tabel 5) en die eerste afleiding wat gemaak kan word, is dat die data as intern betroubaar bestempel kan word, soos bevestig deur die twee Cronbach Alpha- konsekwentheidskoëffisiënte (bokant 0.82). Die vraelys word as inhoudsgeldig gereken, na aanleiding van Briggs (2005) se navorsing, met gebruikmaking van dieselfde Likertskaal-ontwerp en -stellings. Die vraelys is ook onderwerp aan 'n loodsondersoek, deur gebruik te maak van die terugvoering van drie dosente in die Fakulteit Natuurwetenskappe, wat oor uitgebreide ervaring ten opsigte van eerstejaaronderrig beskik. Die effens aangepaste vraelys is gevolglik ook as relatief siggeldig beskou.

Die data, ten opsigte van die twee latente konstrukte (rolbelangrikheid en rolvaardigheid) is vervolgens onderwerp aan ' $n$ variant van eksploratiewe faktoranalise, naamlik hoofkomponent-analise (Principal Component Analysis), nadat daar, volgens die kriteria van Field (2005:628-630), eers vasgestel is of dit geskik is daarvoor. Die data is as gepas vir voorgemelde analise bevind (vergelyk Tabel 5), aangesien die Kaiser-Meyer-Olkin-statistiek (KMO) vir steekproeftoereikendheid eerstens heelwat hoër as die minimum-afsnywaarde van 0.6 was, en tweedens aangesien Bartlett se toets vir sferisiteit op statisties betekenisvolle 
TABEL 1: Biografiese analise van respondente.

\begin{tabular}{|c|c|c|c|}
\hline Biografiese veranderlike & Kategorieë & $N$ & $\%$ \\
\hline \multirow[t]{3}{*}{ Geslag } & Vroulik & 31 & 58.49 \\
\hline & Manlik & 22 & 41.51 \\
\hline & Totaal & 53 & 100.00 \\
\hline \multirow[t]{4}{*}{ Etniese groep } & Swart & 17 & 32.08 \\
\hline & Ander & 6 & 11.32 \\
\hline & Wit & 30 & 56.60 \\
\hline & Totaal & 53 & 100.00 \\
\hline \multirow[t]{4}{*}{ Huistaal } & Afrikaans & 18 & 33.96 \\
\hline & Engels & 20 & 37.73 \\
\hline & Ander taal & 15 & 28.30 \\
\hline & Totaal & 53 & 100.00 \\
\hline \multirow[t]{3}{*}{ Jare by Universiteit van Johannesburg (sedert 2005) } & $0-5$ jaar & 24 & 47.06 \\
\hline & 6 jaar + & 27 & 52.94 \\
\hline & Totaal & 51 & 100.00 \\
\hline \multirow{3}{*}{ Jare onderrigervaring in hoër onderwys } & 6-10 jaar & 15 & 28.85 \\
\hline & 11 jaar + & 20 & 38.46 \\
\hline & Totaal & 52 & 100.00 \\
\hline \multirow[t]{4}{*}{ Jare onderrigervaring vir eerstejaarstudente } & $0-5$ jaar & 17 & 32.69 \\
\hline & 6-10 jaar & 15 & 28.85 \\
\hline & 11 jaar + & 20 & 38.46 \\
\hline & Totaal & 52 & 100.00 \\
\hline
\end{tabular}

TABEL 2: Beskrywing van hoofpligte en verantwoordelikhede wat met die agt kern-dosenterolle geassosieer word.

\begin{tabular}{ll}
\hline Kern-dosenterolle & Belangrike rolverpligtinge en -verantwoordelikhede \\
\hline Bestuurder & Organiseerder; Studieleier; Hulpbronbeplanner \\
Spanwerker & Bydraer; Medewerker; Ondersteuner \\
Kursusontwerper & Kurrikulumontwerper; Kursusontwikkelaar; Kurrikulumresensent \\
Vakkundige & Vakkundige deskundige of spesialis; Inligtingvormer \\
Navorser & Ondersoeker; Skepper; Wetenskaplike kommunikeerder \\
Onderriggewer & Dosent; Leerfasiliteerder; Assesseerder van leer \\
Konsultant & Ondersteunende eweknie vir ander kollegas; Deskundige vennoot \\
Voorligter & Studentementor; Raadgewer; Tutor \\
\hline
\end{tabular}

wyse aantoon dat die korrelasiematriks nie 'n sogenaamde identiteitsmatriks is nie, maar korrelasies bevat wat as geskik vir hoofkomponent-analise gereken kan word.

Tabelle 3 en 4 toon dat agt faktore onderskeidelik ten opsigte van beide latente konstrukte 1 (Rolbelangrikheid) en 2 (Rolvaardigheid) onttrek is. Dosente se rolle as bestuurders, spanwerkers en kursusontwerpers verklaar meer as 70\% van die konstruk rolbelangrikheid. Insgelyk verklaar dosente se bevoegdheid in die uitvoering van dieselfde drie rolle meer as $76 \%$ van die konstruk rolvaardigheid. Deur die Kaiserkriterium, wat 'n eiewaarde ('Eigenvalue') van meer as 1.0 vereis (Field 2005:632-633), toe te pas, word die dosentrolle van bestuurder en spanwerker inderdaad as onderliggende hoofkomponente van die data verkry.

\section{Empiriese bevindinge \\ Geslagspesifieke menings oor rolbelangrikheid}

Die menings van vroue- vergeleke met mansdosente ten opsigte van hul persepsie van die belangrikheid van elk van die agt rolle (Tabel 6) word uiteengesit deur die gesamentlike getal en persentasie van mans- en vrouedosente wat onderskeidelik 'hoër' belangrikheidswaardes per rol aangedui het ('n 4 [belangrik] of 'n 5 [baie belangrik]).
Soos in die geval van die Briggs-studie (2005:260), is al agt rolle oor die algemeen as belangrik tot baie belangrik beskou. Die rolle van onderriggewers (wat leer en die toepassing van kennis fasiliteer) en vakkundiges (wat oor voldoende relevante kennis beskik om oor te dra) is as belangrik beoordeel. Die rol van konsultante (wat as ondersteunende eweknieë en raadgewers vir hul eie kollegas optree) is deur die minste respondente as belangrik aangedui. Net meer as twee derdes van die respondente het die konsultanterol as belangrik of baie belangrik geag, vergeleke met byna $90 \%$ wat 'n ooreenstemmende mening oor die onderriggewer- en vakkundige rolle gehuldig het. Hierdie bevinding is ook bevestig deur Corkill et al. (2011:126) in 'n soortgelyke ondersoek, waarby Britse akademici in die natuurwetenskappe betrokke was.

Die gemiddelde belangrikheidswaarde deur vrouedosente aangedui, is vier en hoër vir alle rolle, terwyl mansdosente effens meer 'konserwatief' is, alhoewel verskille (met die uitsondering van die rolle van kursusontwerper en voorligter) relatief onbenullig is. Beide geslagte het hul rol as onderriggewers as prioriteit aangedui, met die rol van kursusontwerper (wat ook as kurrikulumontwerper en resensent optree) tweede belangrikste vir vrouedosente, terwyl die vakkundige rol 'n ooreenstemmende plek 
TABEL 3: Hoofkomponent-analise ten opsigte van rolbelangrikheid: Eiewaardes en totale verklaarde variansie.

\begin{tabular}{|c|c|c|c|c|c|c|c|c|c|}
\hline \multirow[t]{2}{*}{ Komponent } & \multicolumn{3}{|c|}{ Aanvanklike eiewaardes } & \multicolumn{3}{|c|}{ Ekstraksietotale van gekwadreerde ladings } & \multicolumn{3}{|c|}{ Rotasietotale van gekwadreerde ladings } \\
\hline & Totaal & $\%$ Variansie & Kumulatiewe \% & Totaal & $\%$ Variansie & Kumulatiewe $\%$ & Totaal & $\%$ Variansie & Kumulatiewe $\%$ \\
\hline 1 & 3.650 & 45.625 & 45.625 & 3.650 & 45.625 & 45.625 & 2.657 & 33.210 & 33.210 \\
\hline 2 & 1.140 & 14.253 & 59.878 & 1.140 & 14.253 & 59.878 & 2.133 & 26.668 & 59.878 \\
\hline 3 & .884 & 11.056 & 70.934 & - & - & - & - & - & - \\
\hline 4 & .748 & 9.345 & 80.279 & - & - & - & - & - & - \\
\hline 5 & .549 & 6.861 & 87.140 & - & - & - & - & - & - \\
\hline 6 & .413 & 5.157 & 92.298 & - & - & - & - & - & - \\
\hline 7 & .362 & 4.531 & 96.829 & - & - & - & - & - & - \\
\hline 8 & .254 & 3.171 & 100.000 & - & - & - & - & - & - \\
\hline
\end{tabular}

Ekstraksiemetode: Hoofkomponent-analise (Principal Components Analysis).

TABEL 4: Hoofkomponent-analise ten opsigte van rolvaardigheid: Eiewaardes en totale verklaarde variansie.

\begin{tabular}{|c|c|c|c|c|c|c|}
\hline \multirow[t]{2}{*}{ Komponent } & \multicolumn{3}{|c|}{ Aanvanklike eiewaardes } & \multicolumn{3}{|c|}{ Ekstraksietotale van gekwadreerde ladings } \\
\hline & Totaal & $\%$ Variansie & Kumulatiewe \% & Totaal & $\%$ Variansie & Kumulatiewe \% \\
\hline 1 & 4.427 & 55.335 & 55.335 & 4.427 & 55.335 & 55.335 \\
\hline 2 & .991 & 12.391 & 67.725 & - & - & - \\
\hline 3 & .664 & 8.297 & 76.022 & - & - & - \\
\hline 4 & .594 & 7.431 & 83.453 & - & - & - \\
\hline 5 & .437 & 5.468 & 88.921 & - & - & - \\
\hline 6 & .395 & 4.933 & 93.854 & - & - & - \\
\hline 7 & .294 & 3.673 & 97.527 & - & - & - \\
\hline 8 & .198 & 2.473 & 100.000 & - & - & - \\
\hline
\end{tabular}

Ekstraksiemetode: Hoofkomponent-analise (Principal Components Analysis).

TABEL 5: Oorhoofse geldigheids- en betroubaarheidsaanduiders van die ingesamelde data.

\begin{tabular}{|c|c|c|c|c|c|}
\hline \multirow{2}{*}{$\begin{array}{l}\text { Latente veranderlikes } \\
\text { (konstrukte) }\end{array}$} & \multirow{2}{*}{$\begin{array}{l}\text { Betroubaarheid: } \\
\text { Cronbach } \\
\text { alpha- koëffisiënte }\end{array}$} & \multicolumn{4}{|c|}{ Hoofkomponent-analise (Principal Component Analysis) } \\
\hline & & $\begin{array}{c}\text { Som van eiewaardes } \\
\text { bokant } 1.0\end{array}$ & $\begin{array}{l}\text { Kaiser-Meyer- } \\
\text { Olkin-waardes } \\
\end{array}$ & $\begin{array}{c}\text { Betekenisvolheid van Bartlett } \\
\text { se toets vir sferisiteit }\end{array}$ & $\begin{array}{l}\% \text { Variansie wat } \\
\text { verklaar word }\end{array}$ \\
\hline $\begin{array}{l}\text { Rolbelangrikheid } \\
\text { ( } 2 \text { komponente) }\end{array}$ & .821 & 4.790 & .766 & $.000 * *$ & 59.878 \\
\hline $\begin{array}{l}\text { Rolvaardigheid } \\
\text { (1 komponent) }\end{array}$ & .882 & 4.427 & .847 & $.000 * *$ & 55.335 \\
\hline
\end{tabular}

${ }^{* *}, p \leq 0.01$

TABEL 6: Opinies van dosente insake rolbelangrikheid (Belangrik [4] plus Baie belangrik [5]).

\begin{tabular}{|c|c|c|c|c|c|c|c|c|c|c|c|c|}
\hline \multirow[t]{2}{*}{$\overline{\text { Rolle }}$} & \multicolumn{4}{|c|}{ Vrouedosente } & \multicolumn{4}{|c|}{ Mansdosente } & \multicolumn{4}{|c|}{ Almal } \\
\hline & $n$ & $N$ & $\%$ & Gem & $n$ & $N$ & $\%$ & Gem & $n$ & $N$ & $\%$ & Gem \\
\hline Bestuurder & 25 & 31 & 80.6 & 4.36 & 16 & 22 & 72.7 & 4.05 & 41 & 53 & 77.4 & 4.23 \\
\hline Spanwerker & 22 & 30 & 73.3 & 4.13 & 15 & 20 & 75.0 & 3.90 & 37 & 50 & 74.0 & 4.04 \\
\hline Kursusontwerper & 27 & 31 & 87.1 & 4.52 & 16 & 22 & 72.7 & 3.86 & 43 & 53 & 81.1 & 4.25 \\
\hline Vakkundige & 28 & 31 & 90.3 & 4.42 & 18 & 21 & 85.7 & 4.38 & 46 & 52 & 88.5 & 4.40 \\
\hline Navorser & 21 & 31 & 67.7 & 4.03 & 17 & 21 & 81.0 & 4.10 & 38 & 52 & 73.1 & 4.06 \\
\hline Onderriggewer & 28 & 31 & 90.3 & 4.55 & 20 & 22 & 90.9 & 4.59 & 48 & 53 & 90.6 & 4.57 \\
\hline Konsultant & 19 & 29 & 65.5 & 4.00 & 16 & 22 & 72.7 & 3.91 & 35 & 51 & 68.6 & 3.96 \\
\hline Voorligter & 28 & 31 & 90.3 & 4.32 & 16 & 22 & 72.7 & 3.96 & 44 & 53 & 83.0 & 4.17 \\
\hline
\end{tabular}

Gem, Gemiddelde Likertskaaltelling.

beklee wat mansdosente betref. Vrouedosente het die belangrikheid van die vakkundige rol ook as waardevol beskou, terwyl mansdosente, teen die verwagting in, die rol van kursusontwerper as hul mins belangrike rol beskou het.

\section{Betekenisvolle verskille in geslagspesifieke persepsies van rolbelangrikheid}

Die nieparametriese statistiese tegniek, die Mann-Whitney $U$-toets, is gebruik om verskille tussen die onderskeie mediane van die response van onderskeidelik vroue- en mansdosente te analiseer. Hierdie statistiese tegniek is as toepaslik beskou, aangesien die responswaardes (menings) nie die normale $t$-verspreiding reflekteer nie, op 'n gewone skaal meetbaar is, asook vergelykbaar is wat grootte betref. Ander onderliggende aannames aan die toets wat ook in berekening gebring is, is die toevalligheid van die steekproef en die onafhanklikheid van waarnemings, wat impliseer dat data wat na een groep respondente verwys, nie die data van 'n ander groep kan beïnvloed nie (Milencović 2011:74). Tabelle 7 en 8 toon die toetsstatistiek en rangordes vir rolbelangrikheid (met geslag as groeperingsveranderlike) ten opsigte van al agt rolle.

Die Mann-Whitney-toets (Tabelle 5 en 6) dui aan dat vrouedosente van eerstejaars (Mediaan $=5$ ) die vertolking van die kursusontwerpersrol as betekenisvol belangriker beskou (op die 99\%-betroubaarheidsvlak) as hul manlike 
eweknieë (Mediaan $=4$, U-waarde $=209.0, p=.005$ ). Cohen se effekgrootte $(r=.36)$ is in die medium tot hoë interval (Milencović 2011:77), wat impliseer dat hierdie bevinding ook matige (tot hoë) praktiese betekenisvolheid het.

\section{Geslagspesifieke menings oor rolvaardigheid}

Die opinies van vroue-, vergeleke met mansdosente, oor hul vermeende vaardigheid in die vertolking van hierdie rolle as dosente word in Tabel 9 aangedui. Die tabel toon die gesamentlike getal en persentasie van mans- en vrouedosente wat onderskeidelik 'hoër' vaardigheidswaardes per rol aangedui het ('n 4 [vaardig] of 'n 5 [hoogs vaardig]).

Respondente het hulself in 'n groot mate as vaardig of hoogs vaardig in die vertolking van die agt rolle beskou. Hul vaardigheid in die vertolking van hul rolle as onderriggewer, vakkundige en voorligter (wat ook as studentetutor, raadgewer en mentor optree), is meer positief beoordeel. Hul persepsie van hulbekwaamheid as navorsers (wat navorsingsbevindinge ondersoek en kommunikeer), bestuurders (wat organiseer, studieleiding behartig en hulpbronne beplan), asook konsultante (wat eweknieë en ander ondersteun) is laer beoordeel. Net meer as die helfte van die respondente het hulself as vaardige navorsers beskou, wat waarskynlik op 'n behoefte aan professionele ontwikkeling dui.

Die gemiddelde vaardigheidsgraderings van vrouedosente was vier of hoër vir sewe van die rolle, met hul persepsie van navorsingsvaardigheid as 'n nie onverwagse uitsondering nie. Minder as die helfte van die vrouedosente het hul navorsingsvaardigheid as voldoende beskou. Mansdosente is minder selfversekerd in die aanduiding van hul vaardighede, met 'n gemiddelde telling van vier of hoër wat slegs ten opsigte van die rolle van onderriggewer en vakkundige

TABEL 7: Mann-Whitney $U$ toetsstatistiek + ten opsigte van rolbelangrikheid.

\begin{tabular}{|c|c|c|c|c|c|c|c|c|}
\hline Toets-items & Bestuurder & Spanwerker & Kursusontwerper & Vakkundige & Navorser & Onderriggewer & Konsultant & Voorligter \\
\hline Mann-Whitney $U$ & 260.500 & 245.000 & 209.000 & 320.500 & 303.000 & 334.000 & 304.500 & 260.500 \\
\hline Wilcoxon W & 513.500 & 455.000 & 462.000 & 551.500 & 799.000 & 587.000 & 557.500 & 513.500 \\
\hline Z-waarde & -1.568 & -1.154 & -2.591 & -0.104 & -0.444 & -0.157 & -0.292 & -1.572 \\
\hline $\begin{array}{l}\text { Benaderde asimptotiese } \\
\text { betekenisvolheid (tweekantig) }\end{array}$ & 0.117 & 0.248 & 0.010 & 0.917 & 0.657 & 0.876 & 0.770 & 0.116 \\
\hline $\begin{array}{l}\text { Eksakte asimptotiese } \\
\text { betekenisvolheid (tweekantig) }\end{array}$ & 0.119 & 0.245 & $.010 * *$ & 0.976 & 0.669 & 0.946 & 0.783 & 0.121 \\
\hline
\end{tabular}

$\dagger$, Groeperingsveranderlike: Geslag.

${ }^{*}, p \leq 0.05 ;{ }^{* *}, p \leq 0.01$

TABEL 8: Rangorde ten opsigte van rolbelangrikheid.

\begin{tabular}{|c|c|c|c|c|c|}
\hline Rolle & $N$ van rol & Geslag & $N$ & Gemid rangorde & Som van rangordes \\
\hline \multirow[t]{2}{*}{ Bestuurder } & 53 & Vroulik & 31 & 29.60 & 917.5 \\
\hline & & Manlik & 22 & 23.34 & 513.5 \\
\hline \multirow[t]{2}{*}{ Spanwerker } & 50 & Vroulik & 30 & 27.33 & 820.0 \\
\hline & & Manlik & 20 & 22.75 & 455.0 \\
\hline \multirow[t]{2}{*}{ Kursusontwerper } & 53 & Vroulik & 31 & 31.26 & 969.0 \\
\hline & & Manlik & 22 & 21.00 & 462.0 \\
\hline \multirow[t]{2}{*}{ Vakkundige } & 52 & Vroulik & 31 & 26.66 & 826.5 \\
\hline & & Manlik & 21 & 26.26 & 551.5 \\
\hline \multirow[t]{2}{*}{ Navorser } & 52 & Vroulik & 31 & 25.77 & 799.0 \\
\hline & & Manlik & 21 & 27.57 & 579.0 \\
\hline \multirow[t]{2}{*}{ Onderriggewer } & 53 & Vroulik & 31 & 27.23 & 844.0 \\
\hline & & Manlik & 22 & 26.68 & 587.0 \\
\hline \multirow[t]{2}{*}{ Konsultant } & 51 & Vroulik & 29 & 26.50 & 768.5 \\
\hline & & Manlik & 22 & 25.34 & 557.5 \\
\hline Voorligter & & Manlik & 22 & 23.34 & 513.5 \\
\hline
\end{tabular}

TABEL 9: Opinies van dosente insake hul rolvaardigheid (Vaardig [4] plus Hoogs vaardig [5]).

\begin{tabular}{|c|c|c|c|c|c|c|c|c|c|c|c|c|}
\hline \multirow[t]{2}{*}{ Rolle } & \multicolumn{4}{|c|}{ Vrouedosente } & \multicolumn{4}{|c|}{ Mansdosente } & \multicolumn{4}{|c|}{ Almal } \\
\hline & $n$ & $N$ & $\%$ & Gem & $n$ & $N$ & $\%$ & Gem & $n$ & $N$ & $\%$ & Gem \\
\hline Bestuurder & 23 & 30 & 76.7 & 4.10 & 10 & 22 & 45.5 & 3.46 & 33 & 52 & 63.5 & 3.83 \\
\hline Spanwerker & 25 & 30 & 83.3 & 4.07 & 15 & 20 & 75.0 & 3.85 & 40 & 50 & 80.0 & 3.98 \\
\hline Kursusontwerper & 24 & 30 & 80.0 & 4.17 & 14 & 22 & 63.6 & 3.73 & 38 & 52 & 73.1 & 3.98 \\
\hline Vakkundige & 24 & 30 & 80.0 & 4.17 & 17 & 21 & 81.0 & 4.05 & 41 & 51 & 80.4 & 4.12 \\
\hline Navorser & 14 & 30 & 46.7 & 3.67 & 14 & 21 & 66.7 & 3.71 & 28 & 51 & 54.9 & 3.69 \\
\hline Onderriggewer & 28 & 30 & 93.3 & 4.50 & 15 & 22 & 68.2 & 4.05 & 43 & 52 & 82.7 & 4.31 \\
\hline Konsultant & 23 & 28 & 82.1 & 4.11 & 10 & 22 & 45.5 & 3.55 & 33 & 50 & 66.0 & 3.86 \\
\hline Voorligter & 25 & 30 & 83.3 & 4.17 & 14 & 22 & 63.3 & 3.82 & 39 & 52 & 75.0 & 4.02 \\
\hline
\end{tabular}

Gem, Gemiddelde Likertskaaltelling. 
toegeken is. Hul vaardighede in die vertolking van hul rolle as bestuurder, konsultant, navorser en kursusontwerper is as effens laer beoordeel. Minder as die helfte van die mansdosente het hulself as vaardige bestuurders en konsultante beskou, wat op nog 'n uitdaging ten opsigte van kapasiteitsbou vir die FYA dui.

\section{Betekenisvolle verskille in geslagspesifieke persepsies van rolvaardigheid}

Die Mann-Whitney $U$-toets is ook gebruik om die verskille tussen die mediane van vroue- en mansdosente se response ten opsigte van rolvaardigheid te analiseer. Tabelle 10 en 11 toon die toetsstatistiek en rangordes aan, met geslag as groeperingsveranderlike.

Vroulike dosente in die natuurwetenskappe het hul vaardighede in die vertolking van onderstaande rolle as betekenisvol hoër as dié van hul manlike eweknieë beskou:

- bestuurder (vrouedosente mediaan $=4$ vs. mansdosente mediaan = 3), $U$-waarde $=205.5, p=.008$ (op die $99 \%$-betroubaarheidsvlak), $r=.34$ ('n bevinding met matige tot hoë praktiese betekenisvolheid)

- kursusontwerper (vrouedosente mediaan $=4$ vs. mansdosente mediaan = 4), $U$-waarde $=244.0, p=.047$ (op die 95\%-betroubaarheidsvlak), $r=.24$ ('n bevinding met lae tot matige praktiese betekenisvolheid)

- onderriggewer (vrouedosente mediaan $=5$ vs. mansdosente mediaan $=4$ ), $U$-waarde $=231.5, p=.026$ (op die $95 \%$-betroubaarheidsvlak), $r=.28$ ('n bevinding met lae tot matige praktiese betekenisvolheid)

- konsultant (vrouedosente mediaan $=4$ vs. mansdosente mediaan = 3), $U$-waarde $=188.0, p=.006$ (op die 99\%-betroubaarheidsvlak), $r=.35$ ('n bevinding met matige tot hoë praktiese betekenisvolheid)

\section{Empiriese sintese}

Hierdie empiriese ondersoek het die volgende noemenswaardige bevindinge gegenereer:

- Rolbelangrikheid (hele groep): Die rolle van onderriggewer en vakkundige is deur die meeste, en die rol van konsultant deur die minste respondente as belangrik beskou.

- Rolbelangrikheid (vroue- versus mansdosente): Beide geslagte het die meeste waarde aan hul rol as onderriggewer geheg, met die vrouedosente wat hul rol as kursusontwerper as tweede belangrikste beskou het, terwyl mansdosente die minste waarde daaraan geheg het. Die verskil in die persepsies van die twee geslagte van die rol van kursusontwerper is as statisties betekenisvol bevind, met 'n matige tot hoë vlak van praktiese betekenisvolheid.

- Rolvaardigheid (hele groep): Hul vermoë om die rol van onderriggewer, vakkundige en voorligter te vertolk, is gunstiger beoordeel as hul vermeende vaardigheid om die rolle van navorser, bestuurder en konsultant te vertolk.

- Rolvaardigheid (vroue- versus mansdosente): Vrouedosente het 'n statisties betekenisvolle hoër dunk van hul eie vaardighede as hul manlike eweknieë, wat betref die vertolking van die rolle van kursusontwerper, onderriggewer, bestuurder en konsultant, met matige tot hoë vlakke van praktiese betekenisvolheid.

\section{Slot}

Die oorgang van studente tot hoër onderwys is nasionaal en internasionaal 'n gewilde navorsingstema, maar weinig is bekend oor die persepsies van akademiese personeel wat oorgangstudente onderrig en wie se tradisionele dosenterolle dus ook in oorgang verkeer. Die uitvoering van strategieë soos Eerstejaar-Ervaringsprogramme (FYE programmes), kredietdraende eerstejaarseminare, akademiese ondersteuningsprogramme en -strukture, tutor- en mentorprogramme en vorme van gespesialiseerde

TABEL 11: Rangorde ten opsigte van rolvaardigheid.

\begin{tabular}{llllll}
\hline Rolle & $N$ van rol & Geslag & $N$ & $\begin{array}{l}\text { Gemid } \\
\text { rangorde }\end{array}$ & $\begin{array}{l}\text { Som van } \\
\text { rangordes }\end{array}$ \\
\hline Bestuurder & 52 & Vroulik & 30 & 30.65 & 919.5 \\
& & Manlik & 22 & 20.84 & 458.5 \\
Spanwerker & 50 & Vroulik & 30 & 27.75 & 832.5 \\
& & Manlik & 20 & 22.13 & 442.5 \\
Kursusontwerper & 52 & Vroulik & 30 & 29.37 & 881.0 \\
& & Manlik & 22 & 22.59 & 497.0 \\
Vakkundige & 51 & Vroulik & 30 & 26.93 & 808.0 \\
& & Manlik & 21 & 24.67 & 518.0 \\
Navorser & 51 & Vroulik & 30 & 25.33 & 760.0 \\
& & Manlik & 21 & 26.95 & 566.0 \\
Onderriggewer & 52 & Vroulik & 30 & 29.78 & 893.5 \\
& & Manlik & 22 & 22.02 & 484.5 \\
Konsultant & \multirow{2}{*}{50} & Vroulik & 28 & 29.79 & 834.0 \\
& & Manlik & 22 & 20.05 & 441.0 \\
Voorligter & 52 & Vroulik & 30 & 28.57 & 857.0 \\
& & Manlik & 22 & 23.68 & 521.0 \\
\hline
\end{tabular}

TABEL 10: Mann-Whitney $U$ toetsstatistiek + ten opsigte van rolvaardigheid.

\begin{tabular}{|c|c|c|c|c|c|c|c|c|}
\hline Toets-items & Bestuurder & Spanwerker & Kursusontwerper & Vakkundige & Navorser & Onderriggewer & Konsultant & Voorligter \\
\hline Mann-Whitney $U$ & 205.500 & 232.500 & 244.000 & 287.500 & 295.000 & 231.500 & 188.000 & 268.000 \\
\hline Wilcoxon W & 458.500 & 442.500 & 497.000 & 518.000 & 760.000 & 484.500 & 441.000 & 521.000 \\
\hline$Z$-waarde & -2.416 & -1.487 & -1.704 & -0.578 & -0.399 & -1.988 & -2.492 & -1.219 \\
\hline $\begin{array}{l}\text { Benaderde asimptotiese } \\
\text { betekenisvolheid } \\
\text { (tweekantig) }\end{array}$ & $.016^{*}$ & 0.137 & 0.088 & 0.564 & 0.69 & $.047^{*}$ & $.013^{*}$ & 0.223 \\
\hline $\begin{array}{l}\text { Eksakte asimptotiese } \\
\text { betekenisvolheid } \\
\text { (tweekantig) }\end{array}$ & $.017^{*}$ & 0.139 & 0.101 & 0.607 & 0.693 & $.044^{*}$ & $.011^{*}$ & 0.236 \\
\hline $\begin{array}{l}\text { Eksakte asimptotiese } \\
\text { betekenisvolheid } \\
\text { (eenkantig) }\end{array}$ & $.008^{* *}$ & 0.076 & $.047^{*}$ & 0.297 & 0.341 & $.026^{*}$ & $.006^{* *}$ & 0.116 \\
\hline
\end{tabular}

$\dagger$, Groeperingsveranderlike: Geslag.

$*, p \leq 0.05 ;{ }^{* *}, p \leq 0.01$ 
kurrikulumontwerp (waaronder grondfasemodules) is kenmerkende pogings deesdae om die toeganklikheid en belyning van kurrikula vir veral eerstejaarstudente in die natuurwetenskappe te bevorder. Hierdie stelling is waar vir die meerderheid universiteite - in Suid-Afrika, asook in die buiteland. Die gemelde strategieë is egter akuut afhanklik van die vermoëns van die dosente van hierdie eerstejaarstudente om proaktief hul tradisionele rolle en optrede aan te pas, ten einde beter ondersteuning aan studente te bied. Hierdie artikel het gefokus op die persepsies van 53 dosente van eerstejaarstudente in die natuurwetenskappe aan die UJ van belangrike rolle wat hulle behoort te beklee en hul geskatte bevoegdheid in die uitvoering daarvan. Die FYA het die navorsing van stapel gestuur, vanweë die oortuiging dat toepaslike optrede deur dosente en gepaardgaande vaardighede geïdentifiseer en ontwikkel behoort te word indien die Fakulteit die akademiese sukses van hul groeiende getal 'nietradisionele' eerstejaarstudente wil verhoog.

Die persepsies van dosente oor hul eie vertolking van die agt internasionaal geïdentifiseerde rolle is via ' $n$ vraelys gepeil. Soos in die geval van Senga Briggs se studie in Skotland in 2005, is al agt rolle oor die algemeen as belangrik tot baie belangrik geag. Die rolle van onderriggewers (wat leer en die toepassing van kennis fasiliteer) en vakkundiges (wat oor voldoende relevante kennis beskik om oor te dra), is egter as die belangrikste beoordeel. Die UJ-dosente het hul vermoë om die rol van onderriggewer, vakkundige en voorligter te vertolk, gunstiger beoordeel as hul vermeende vaardigheid om die rolle van navorser, bestuurder en konsultant te vertolk.

Vrouedosente het 'n statisties betekenisvolle hoër dunk van hul eie vaardighede as hul manlike eweknieë. Voorts het minder as die helfte van die mansdosente hulself as bevoegde bestuurders en konsultante beskou. Professionele ontwikkeling, gerig op die meer bedrewe vertolking van (veral) die rolle van kursusontwerper, onderriggewer, kursusbestuurder en ewekniekonsultant, is as die belangrikste behoeftes van die groep eerstejaarsdosente geïdentifiseer.

\section{Erkenning}

Die outeurs spreek hul opregte danken waardering uit teenoor die eerstejaardosente van 2012 en 2013 van die Fakulteit Natuurwetenskappe aan die Universiteit van Johannesburg, wat bereidwillig was om aan die navorsing deel te neem. Die Eerstejaar-Akademie van die Fakulteit verdien spesiale vermelding vir hul deurlopende ondersteuning van en belangstelling in die projek.

\section{Mededingende belange}

Die outeurs verklaar hiermee dat hulle geen finansiële of persoonlike verbintenis het met enige party wat hulle voordelig of nadelig in die skryf van hierdie artikel kon beïnvloed nie.

\section{Outeursbydrae}

Die artikelkoördinasie, -ontwerp, empiriese analises, tabelle en opsommings is behartig deur G.J.J. (Universiteit van
Johannesburg). Die literatuurstudie, empiriese opname, figure en die literatuurverwysings is behartig deur M.J. (Universiteit van Johannesburg). Die interpretasies, skryf en proeflees is gesamentlik behartig deur beide outeurs.

\section{Literatuurverwysings}

Akerlind, G.S., 2005, 'Academic growth and development - How do university academics experience it?', Higher Education 50, 1-32. http://dx.doi.org/10.1007/ s10734-004-6345-1

Arbuckle, J. \& Williams, B.D., 2003, 'Students' perceptions of expressiveness: Age and gender effects on teacher evaluations', Sex Roles: A Journal of Research 49 (9-10), 507-516. http://dx.doi.org/10.1023/A:1025832707002

Bowles, A., Dobson, A., Fischer, R. \& McPhail, R., 2011, 'An exploratory investigation into first year student transition to university', Research and Development in Higher Education: Higher Education on the Edge 34, 61-71.

Boyer, E., 1997, Scholarship reconsidered: Priorities of the professoriate, Carnegie Commission, New York, NY.

Briggs, S., 2005, 'Changing roles and competencies of academics', Active Learning in Higher Education 6(3), 256-268. http://dx.doi.org/10.1177/1469787405057753

Cavote, S. \& Kopera-Frye, K., 2007, 'Nontraditional student persistence and first year experience courses', Journal of College Student Retention 8 (4), 477-489. http:// dx.doi.org/10.2190/Q166-2010-51T4-852L

Corkill, H., Elkington, S. \& Lawrence, L., 2011, 'Exploring the parallel universes of staff and student transitions in higher education', Research and Development in Higher Education: Reshaping Higher Education 34, 118-129.

Cornelius, S. \& Higgison, C., 2000, 'The tutor's role and effective strategies for online tutoring', in C. Higgison (ed.), Online Tutoring e-Book, Chapter 2, Herriot-Watt University, Edinburgh, and The Robert Gordon University, Aberdeen, Scotland.

Field, A., 2005, Discovering statistics using SPSS, 2th ed., Sage Publications Ltd., London.

Giancola, J.K., Munz, D.C. \& Trares, S., 2008, 'First versus continuing generation adult students on college perceptions. Are differences actually because of demographic variances?', Adult Education Quarterly 58(3), 214-228. http:// dx.doi.org/10.1177/0741713608314088

Grayson, D.J., 1997, 'A holistic approach to preparing disadvantaged students to succeed in tertiary science studies. Part II. Outcomes of the Science Foundation Programme', International Journal of Science Education 19(1), 107-123. http:// dx.doi.org/10.1080/0950069970190108

Hay, H.R. \& Marais, F., 2004, 'Bridging programmes: Gain, pain or all in vain', South African Journal of Higher Education 18(2), 59-75. http://dx.doi.org/10.4314/ sajhe.v18i2.25454

Heppner, P.P. \& Heppner, M.J., (eds.), 2004, Writing and publishing your thesis, dissertation and research. A guide for students in the helping professions, Brooks/ Cole-Thomson Learning, Belmont, California.

Jacobs, M., 2010, 'A framework for the placement of university students in science programmes', unpublished doctoral thesis, University of Free State, Bloemfontein.

Kift, S., 2008, 'The next, great first year challenge: Sustaining, coordinating and embedding coherent institution-wide approaches to enact the FYE as "everybody's business"', First Year in Higher Education Conference, Hobart, Australia.

Kift, S., 2009, 'Articulating a transition pedagogy to scaffold and to enhance the first year student learning experience in Australian higher education', Final report for ALTC Senior Fellowship Program, Queensland University of Technology, Brisbane, Australia.

Leibowitz, B., Van der Merwe, A. \& Van Schalkwyk, S., 2009, 'Introduction Perspectives on the first-year experience', in B. Leibowitz, A. van der Merwe \& $\mathrm{S}$. van Schalkwyk (eds.), Focus on first-year success: Perspectives emerging from South Africa and beyond, pp. 3-11, SUN Media, Stellenbosch.

Lentell, H., 2003, 'The importance of the tutor in open and distance learning', in A. Tait \& R. Mills (eds.), Rethinking learner support in distance education, pp. 64-76, RoutledgeFalmer, London.

Meyers, N. \& Ryan, Y., 2008, Commentary on first year curriculum case studies: Staff development perspective, Australian Learning and Teaching Council, Queensland University of Technology, Brisbane, Australia.

Milenković, Z.M., 2011, 'Application of Mann-Whitney $U$ test in research of professional training of primary school teachers', Metodicki Obzori 6(1), 73-79.

Olive, T. \& Russ, S., 2010, 'Desire for higher education in first-generation hispanic college students', International Journal of Interdisciplinary Social Sciences 5(1), 377-389.

Pike, G.R. \& Kuh, G.D., 2005, 'First- and second-generation college students: A comparison of their engagement and intellectual development', Journal of Higher Education 76(3), 276-300. http://dx.doi.org/10.1353/jhe.2005.0021

Republic of South Africa, 2012, Green paper for post-school education and training, Department of Higher Education and Training, Pretoria.

University of Georgia, n.d., viewed 24 October 2013, from http://www.uga.edu

University of Johannesburg (UJ), 2009, Proposal for the implementation of a First Year Experience (FYE) programme at UJ, unpublished internal document, UJ Senate, Johannesburg.

University of Johannesburg (UJ), 2013, Enrolment report: First semester, unpublished internal report, Faculty of Science, University of Johannesburg, Johannesburg. 